\title{
Research on the Coal Seam Permeability-Increasing Technology via High-Pressure Water Jet Reaming and Its Application
}

\author{
Xingang Niu $\mathbb{D}^{1,2,3,4}$ Biming Shi, ${ }^{1,2}$ Zhigang Zhang, ${ }^{3,4}$ and Yongjiang Zhang ${ }^{3,4}$ \\ ${ }^{1}$ State Key Laboratory of Mining Response and Disaster Prevention and Control in Deep Coal Mines, Anhui University of Science \\ and Technology, Huainan, Anhui 232001, China \\ ${ }^{2}$ School of Energy and Security, Anhui University of Science and Technology, Huainan, Anhui 232001, China \\ ${ }^{3}$ State Key Laboratory of the Gas Disaster Detecting, Preventing and Emergency Controlling, China Coal Technology and \\ Engineering Group, Chongqing Research Institute, Chongqing 400037, China \\ ${ }^{4}$ Gas Research Branch, China Coal Technology and Engineering Group, Chongqing Research Institute, Chongqing 400037, China
}

Correspondence should be addressed to Xingang Niu; xingang202012@163.com

Received 4 January 2021; Revised 31 January 2021; Accepted 19 February 2021; Published 4 March 2021

Academic Editor: Zhigang Tao

Copyright (C) 2021 Xingang Niu et al. This is an open access article distributed under the Creative Commons Attribution License, which permits unrestricted use, distribution, and reproduction in any medium, provided the original work is properly cited.

\begin{abstract}
Aiming at the problem of coal and gas outburst prevention and control in serious outburst dangerous coal seam under complex geological conditions in Qidong Coal Mine, the water jet drilling and expanding integrated device was used to implement the measures that expand holes and increase permeability by high-pressure water at a 912 working face. The experimental results show that when the pump pressure is between $13 \mathrm{MPa}$ and $15 \mathrm{MPa}$, the particle size of pulverized coal can be effectively reduced and the discharge of pulverized coal can be increased. The coal output of a single hole is $0.8 \sim 2.3 \mathrm{t} / \mathrm{m}$, with an average of $1.1 \mathrm{~m} / \mathrm{t}$. The unreamed conventional borehole has a single-hole initial gas drainage rate of $50.74 \mathrm{~m}^{3} / \mathrm{d}$ and a single-hole cumulative gas drainage rate of $736.12 \mathrm{~m}^{3}$ within 30 days. The initial single-hole gas drainage volume of the reaming borehole is $178.74 \mathrm{~m} / \mathrm{d}$, and the cumulative single-hole gas drainage volume in 30 days is $2227.57 \mathrm{~m}^{3}$. After reaming, the initial gas drainage scalar of a single hole increases 3.52 times of the original unreamed conventional drilling and the average cumulative gas drainage scalar of a single hole reaches 3.03 times of the original unreamed conventional drilling. This technology and equipment have a good promotion and application value in gas treatment of soft, low-permeable coal seams.
\end{abstract}

\section{Introduction}

As is known to all, coal and gas outburst is the result of a comprehensive action of in situ stress, gas, and physical and mechanical properties of coal $[1,2]$. Although the physical and mechanical properties of coal and rock mass are inherent, which are difficult to change, the in situ stress and gas pressure of coal and rock mass around the mining face can be changed by taking certain technical means. Affected by the superposition of gravity stress, tectonic stress, and mining stress, there is a stress concentration area around the mining face. If effective pressure relief measures are taken, the stress concentration in a high-stress area can be greatly reduced and the peak stress can be far away from the roadway. Due to the serious coal and gas outburst disasters, the geological structure of the mining area is more complex, the coal seam is soft, and the permeability is very low. The typical mining areas are the Liang Huai mining area, Yuxi mining area, Yangquan mining area, etc. This characteristic determines the poor effect of coal seam extraction. However, if the appropriate measures of pressure relief and permeability increase are taken, the problem of gas drainage can be solved. Therefore, the effective measures of pressure relief and permeability increase become the fundamental solution to coal and gas outburst. At present, the common methods of coal seam pressure relief and permeability enhancement mainly include coal seam blasting, borehole pressure relief, and coal seam water injection. Among them, drilling pressure relief is the most widely used. Its principle is to release part of the stress of coal and rock mass and increase the permeability of the coal seam through drilling construction and later deformation. However, due to the limitation of the borehole 
diameter, the pressure relief range and permeability enhancement effect are often very limited and the stress is easy to recover in a short time. It is often necessary to take two or more times of repeated pressure relief, which is not only a large amount of work but also easy to cause damage on the roadway support. It greatly reduces the ability of the roadway to resist dynamic disasters such as coal and gas outburst.

In view of the coal and gas outburst theory and prevention measures, predecessors have done a lot of in-depth research and also achieved many fruitful research results. Wang et al. [3] chose the soft rock layer as the first protective layer of the deep coal seam in Luling Coal Mine in the Huaibei Coalfield. At the same time, they established the safety engineering of the three-dimensional drainage and utilization system. According to the characteristics of the mining of the lower protective layer, He et al. [4] put forward the basic assumptions of the coal gas-solid coupling model and put forward the permeability improvement coefficient of equivalent interlayer spacing. Li et al. [5] proposed a threedimensional coextraction strategy of coal and coalbed methane. The strategy includes three levels of three-dimensional gas prevention and control methods. The first level is the combination of surface and underground gas extraction methods to achieve joint extraction of surface and underground gas. The second level is the full-coverage mining of the coal resources to be mined, in order to realize the combined mining of drilling holes across the coal seam and along the coal seam. The third layer is the optimization of surface and underground mining and utilization systems to realize the full utilization of coalbed methane and achieve the goal of coextraction of coal and coalbed methane. Fu et al. [6] analysed the coal and gas outburst accidents that occurred in China from 2008 to 2018 and studied their macro rules. In order to better understand the causes of coal and gas outbursts, this article uses the 24 models to analyse coal and gas accidents and proposes measures to prevent accidents from two aspects: gas (risk control) and human (behavioural safety). Chen et al. [7] carried out a hydraulic flushing technology of transverse joint drilling and established the multiphysics coupling model. Then, the damage range and permeability evolution after hydraulic washing were studied, and the mechanism was proposed. Cheng et al. [8] demonstrated the effect of using hydraulic fracturing to prevent gas disasters and it can effectively improve the efficiency of gas drainage. Gas production increased by $62.12 \%$, and the number of presuction holes decreased by $45.66 \%$. Zhou et al. [9] reported the results of laboratory experiments using cement-based high-water content slurries with different water-cement ratios for coal injection. They found that as the water-cement ratio increased, the fluidity of the mud and its setting time increased. Other research results are also shown in literatures [10-23]. Aiming at the high-pressure water jet technology, the main achievements are as follows. Ke et al. [24] proposed a steady-state flow model and used it to calculate the effective radius after the high-pressure water jet is slotted. Field measurements at Zhongliangshan Coal Mine show that both the steady-state flow model and the thermal-hydraulic-mechanical coupling model can accurately represent the effective radius and the thermal- hydraulic-mechanical coupling model provides more information about the extraction time. Zhang et al. [25] determined the impact of key parameters on slotting depth; these key parameters include the nozzle diameter, jet pressure, speed, and slotting time. They established and verified the waterjet groove depth calculation model based on the grooving experiments under different working conditions. Jun et al. [26] took Shihuatian Coal Mine which is located in Guizhou province, China, as an example; a high-pressure water jet is used to open holes in the coal seam to relieve the gas pressure inside the coal seam and increase the permeability of the coal seam, thereby improving the efficiency of gas drainage and eliminating outburst risk. The results show that the gas drainage efficiency of the long-hole drilling is significantly improved. Zhang and Zou [27] derived the velocity distribution law of the water jet section according to the law of conservation of momentum. Then, according to the linear relationship between the impact force of the water jet and the erosion amount, the pressure decay law of the water jet and the Mohr-Coulomb criterion, the change of the depth of the water tank with time, and the influence range of the water jet tank are determined. Zhao and Guo [28] set up a model of a high-pressure water jet hitting a coal target and researched the coal cracking mechanism under impact load. Then, theoretically and numerically, the characteristics and pressure distribution of the high-pressure water jet, the propagation characteristics of the stress wave in the coal, the mechanical properties of different coal particles, and the fracture characteristics of the coal under the erosion of the high-pressure water jet are studied. Other research results are also shown in literatures [29-40].

To sum up, the existing technical means to prevent coal and gas outburst mainly have the disadvantages of large construction quantity, high construction cost, and long construction time. Therefore, this paper presents a new method of high-pressure water jet reaming for pressure relief and permeability enhancement. By using the integrated device of water jet drilling and expanding, the high-pressure water is used to expand the hole to strengthen the pressure relief and effectively increase the permeability of the coal seam. The field test shows that the reaming process can effectively reduce the particle size of expanded pulverized coal, improve the discharge of pulverized coal, reduce the stress concentration of coal and rock mass around the mining space, and greatly increase the permeability of the coal seam, which can provide a certain reference for mines with similar conditions.

\section{Description of the Study Site}

Qidong Coal Mine is located in Qixian town, Suzhou city, northern Anhui province. The geographical location of Qidong Coal Mine is shown in Figure 1.

The 912 working face in the first mining area of Qidong Coal Mine adopts an inclined strip layout. The buried depth of the working face is $450-606 \mathrm{~m}$, the average strike width is $201 \mathrm{~m}$, the inclined length is $1302 \mathrm{~m}$, the average dip angle of the coal seam is $8^{\circ}$, and the average thickness is $3.5 \mathrm{~m}$. The firmness coefficient of the coal seam is 0.16 and the permeability coefficient is $0.0429 \mathrm{~m}^{2} /\left(\mathrm{MPa}^{2} \cdot \mathrm{d}\right)$. It is a typical soft 


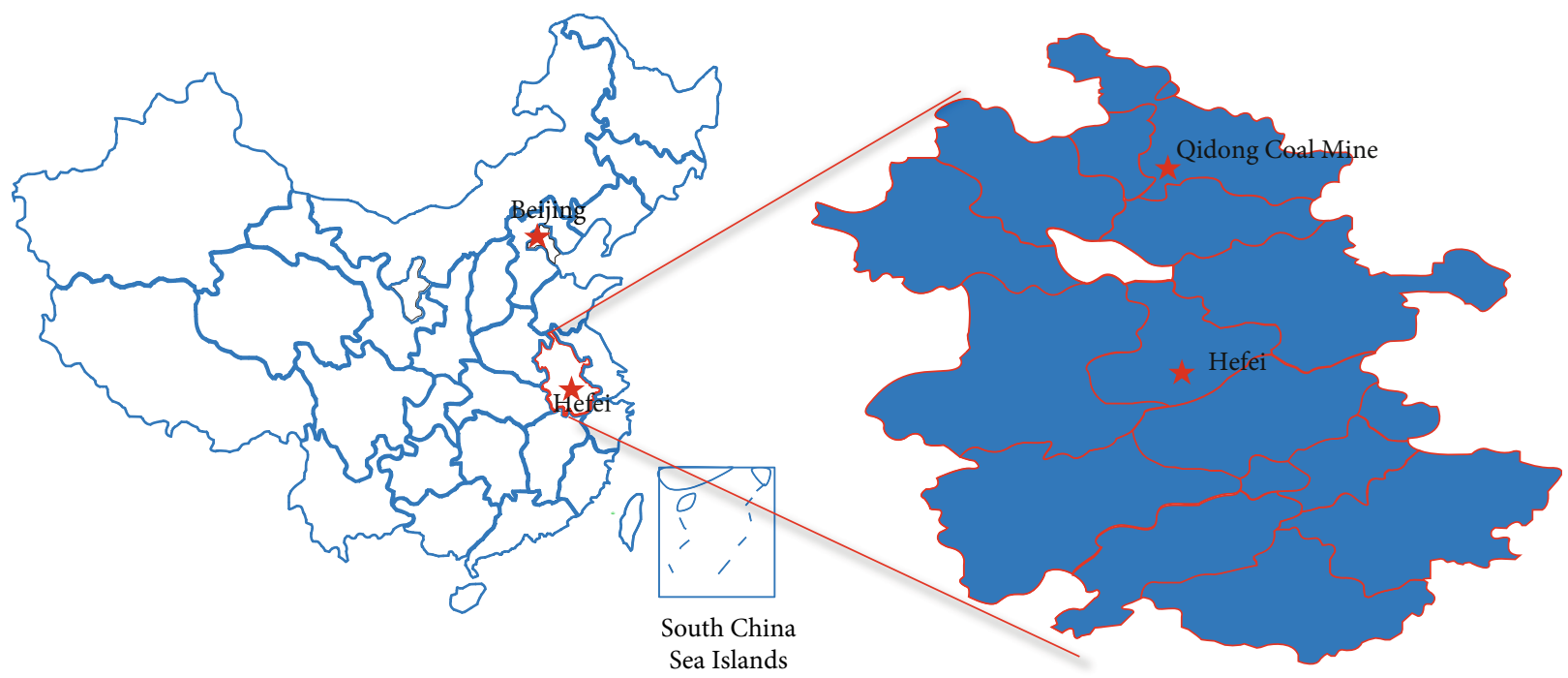

FIgUre 1: Geographical location of Qidong Coal Mine.

\begin{tabular}{|c|c|c|c|}
\hline Rock & $\begin{array}{l}\text { Cumulative } \\
\text { thickness }\end{array}$ & $\begin{array}{l}\text { Layer } \\
\text { thickness }\end{array}$ & Lithology \\
\hline Mudstone & $44.3 \mathrm{~m}$ & $4.7 \mathrm{~m}$ & \multirow{7}{*}{$\begin{array}{l}\text { Roof: the main roof is mainly } \\
\text { sandstone with an average } \\
\text { uniaxial compressive strength } \\
\text { of } 71.5 \mathrm{MPa} \text { and thickness of } \\
7.2 \mathrm{~m} \text {. }\end{array}$} \\
\hline $7_{1}$ coal seam & $39.6 \mathrm{~m}$ & $2.1 \mathrm{~m}$ & \\
\hline Mudstone & $37.5 \mathrm{~m}$ & $3.9 \mathrm{~m}$ & \\
\hline $7_{2}$ coal seam & $33.6 \mathrm{~m}$ & $0.7 \mathrm{~m}$ & \\
\hline Mudstone & $32.9 \mathrm{~m}$ & $2.0 \mathrm{~m}$ & \\
\hline Fine sandstone & $30.9 \mathrm{~m}$ & $10.0 \mathrm{~m}$ & \\
\hline $8_{1}$ coal seam & $20.9 \mathrm{~m}$ & $1.2 \mathrm{~m}$ & \\
\hline Fine sandstone & $19.7 \mathrm{~m}$ & $8.0 \mathrm{~m}$ & \multirow{2}{*}{$\begin{array}{l}\text { The coal seam } 9 \text { is black and } \\
\text { in a powder form with a } \\
\text { fragment shape and a glass } \\
\text { luster. }\end{array}$} \\
\hline $8_{2}$ coal seam & $11.7 \mathrm{~m}$ & $1.5 \mathrm{~m}$ & \\
\hline Mudstone & $10.2 \mathrm{~m}$ & $3.0 \mathrm{~m}$ & \multirow{6}{*}{$\begin{array}{l}\text { Floor: the immediate floor is } \\
\text { mudstone and silty sand, and } \\
\text { its uniaxial compressive } \\
\text { strength is } 32.8 \mathrm{MPa} \text { with } \\
\text { thickness of } 8.0 \mathrm{~m} \text {. }\end{array}$} \\
\hline Fine sandstone & $7.2 \mathrm{~m}$ & $7.2 \mathrm{~m}$ & \\
\hline Coal seam 9 & & $3.5 \mathrm{~m}$ & \\
\hline Mudstone & $8.0 \mathrm{~m}$ & $8.0 \mathrm{~m}$ & \\
\hline $\begin{array}{l}\text { Aluminous } \\
\text { Mudstone }\end{array}$ & $15.5 \mathrm{~m}$ & $7.5 \mathrm{~m}$ & \\
\hline Fine sandstone & $20.2 \mathrm{~m}$ & $4.7 \mathrm{~m}$ & \\
\hline
\end{tabular}

Figure 2: Geological columnar section.

and low-permeability coal seam. Coal seam 9 has no direct roof; the basic roof is fine sandstone, $7.2 \mathrm{~m}$ thick; and the uniaxial compressive strength is $71.5 \mathrm{MPa}$. The floor of coal seam 9 is mudstone with a thickness of $8.0 \mathrm{~m}$ and uniaxial compressive strength of $32.8 \mathrm{MPa}$. The comprehensive histogram of coal seam 9 is shown in Figure 2. 


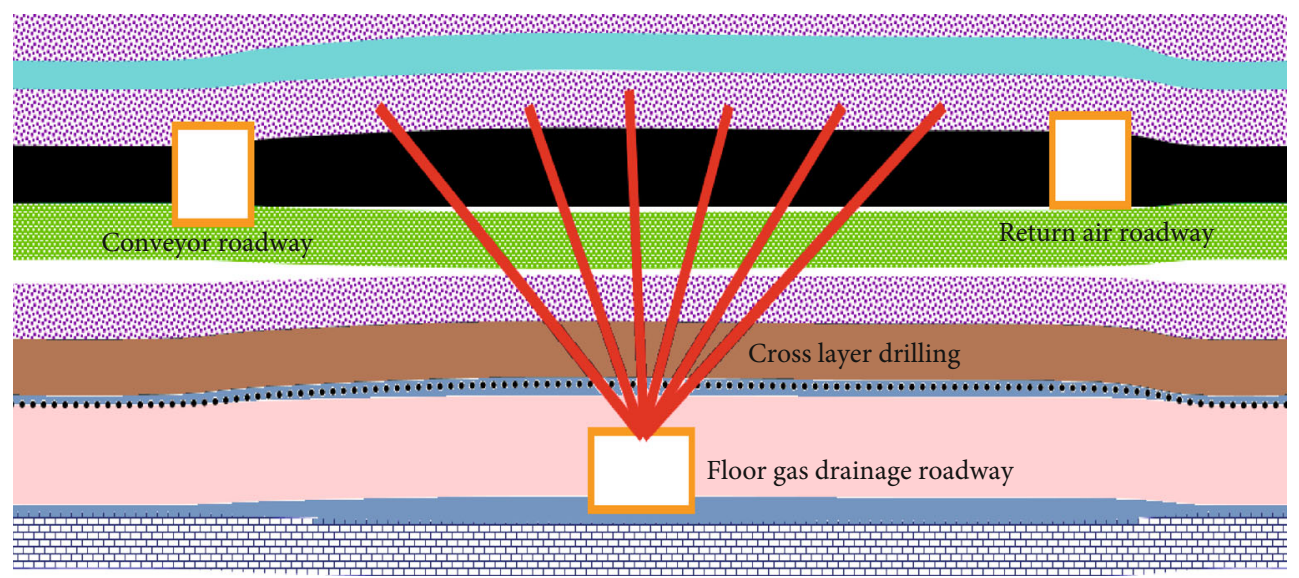

FiguRE 3: Schematic diagram of the perforating drill hole.
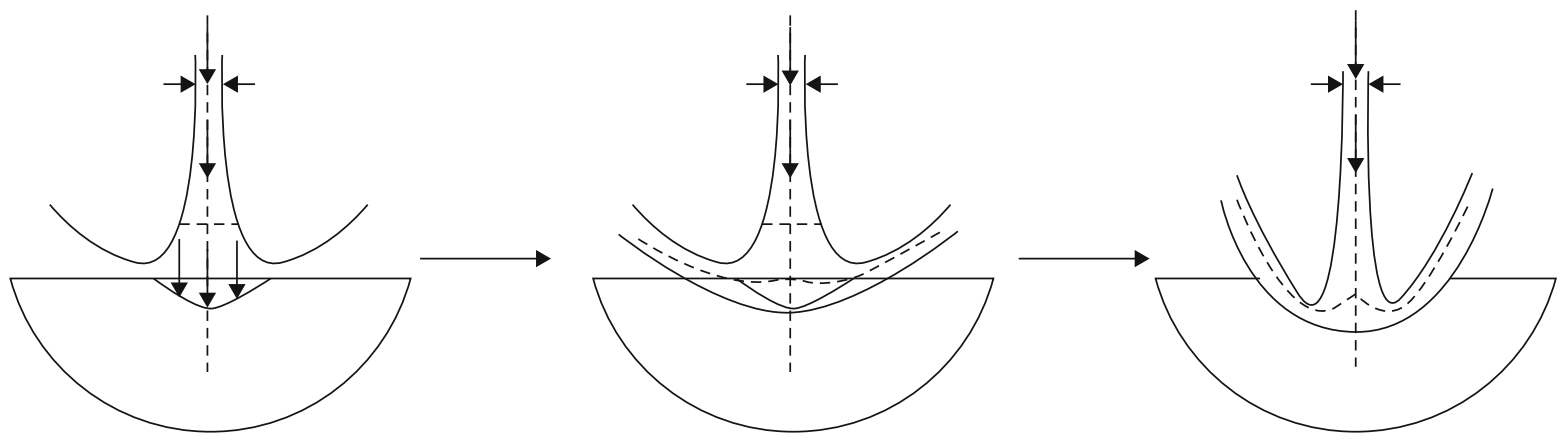

FIGURE 4: Rock fracture mechanism of the high-pressure water jet.

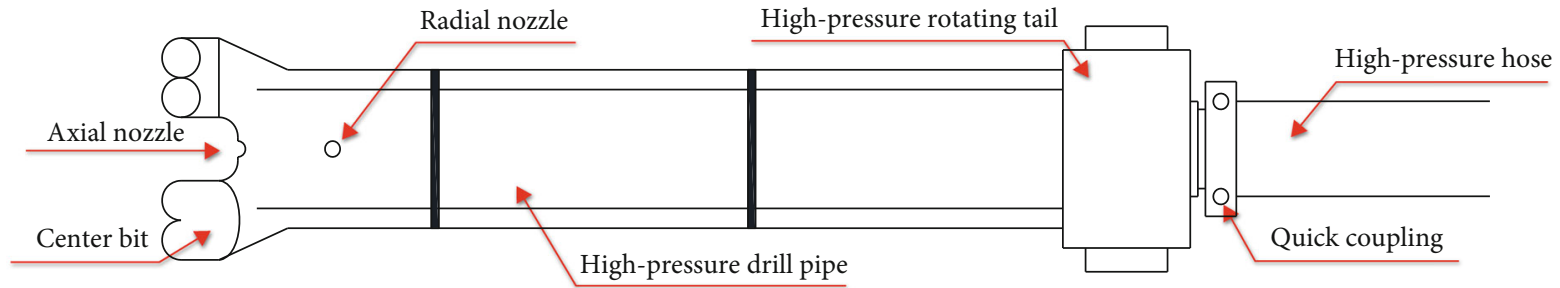

Figure 5: High-pressure water jet drilling and reaming integrated device.

Coal seam 9 is an outburst coal seam. The 912 working face is located in the outburst danger area. The 912 working face adopts outburst prevention measures in the prepumping area of floor dense through layer drilling. The grid size is no more than $5 \mathrm{~m} \times 8.6 \mathrm{~m}$ (spacing $\times$ row spacing), and the design length of drilling is $70 \sim 110 \mathrm{~m}$, as shown in Figure 3. The measured gas pressure of coal seam 9 in 1 mining area is $2.2 \sim 2.7 \mathrm{MPa}(-450 \mathrm{~m}$ elevation). The coal seam is soft and the permeability is poor. The hole collapse and plugging are serious in the drilled hole, and the prepumping effect is poor. It needs to introduce the advanced coal seam permeability increasing technology to solve the problem. Therefore, it is necessary to carry out experimental research on the regional outburst elimination technology of the 912 working face to eliminate the "blank zone" of outburst prevention and improve gas drainage effect. The test site is selected in the floor gas drainage roadway of coal seam 9 .

\section{The Construction Technology and Scheme}

3.1. The Coal Fracturing Mechanism of the High-Pressure Water Jet. High-pressure water can form a strong impact on the surface of coal and rock mass after passing through a small jet hole and transfer its energy to the object. This kind of force is enough to overcome the molecular force between particles and cause the destruction of coal and rock mass in a certain depth range. The destruction process of the jet on coal and rock mass materials is very complex, which is not only related to jet working conditions but also closely related to the heterogeneity of materials. The main failure modes of rock are plastic failure of plastic material under shear stress and brittle failure of brittle material under tensile stress. But whether it is plastic failure or brittle failure, it can only occur when the material stress exceeds the shear or tensile strength under the impact of the jet. When the jet 


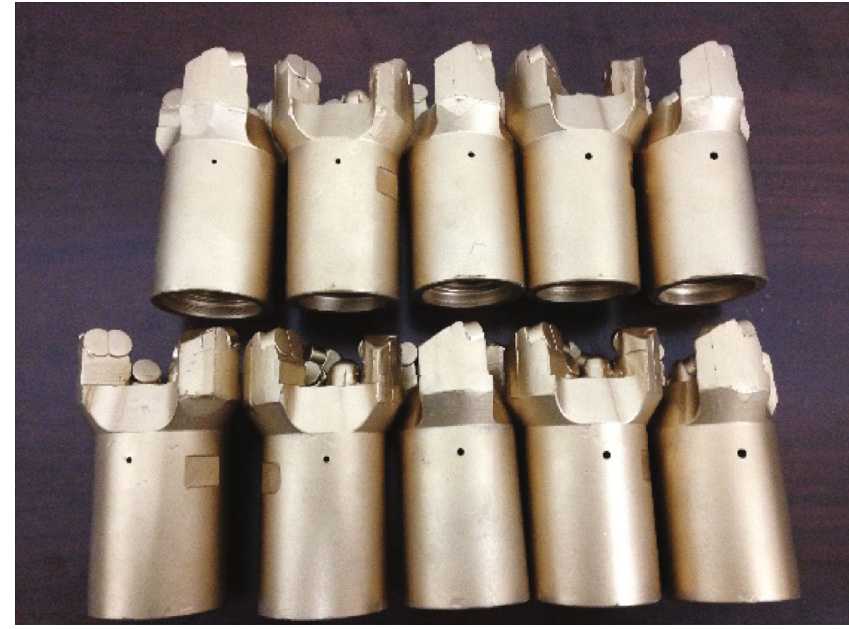

(a) Center bit

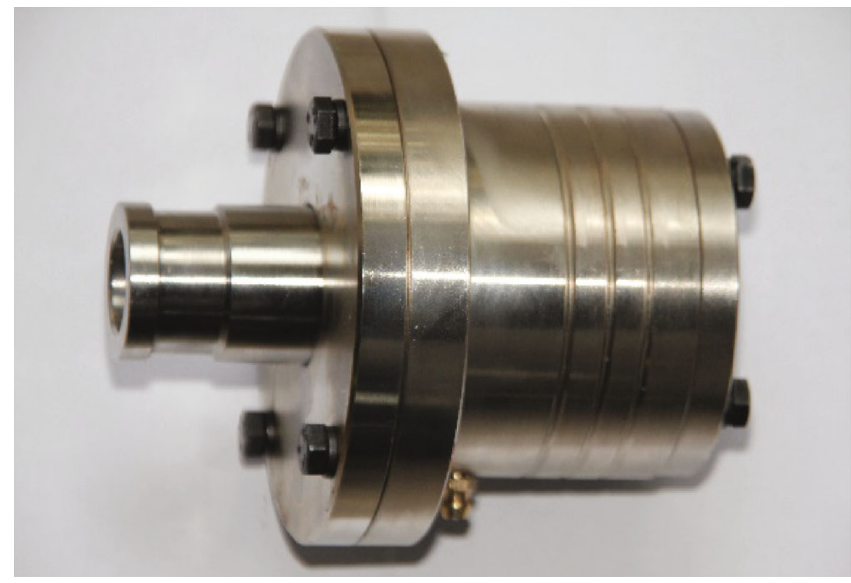

(c) Quick coupling

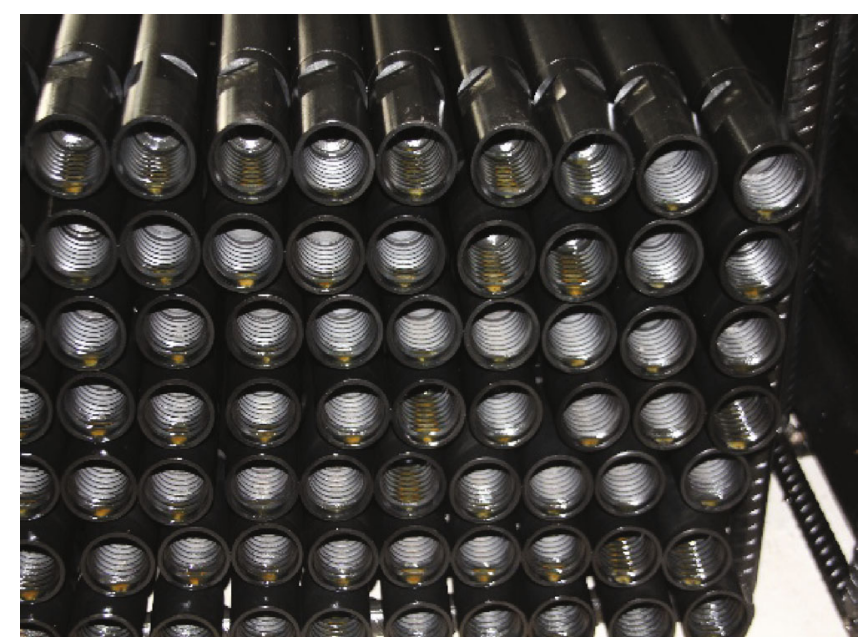

(b) High-pressure drill pipe

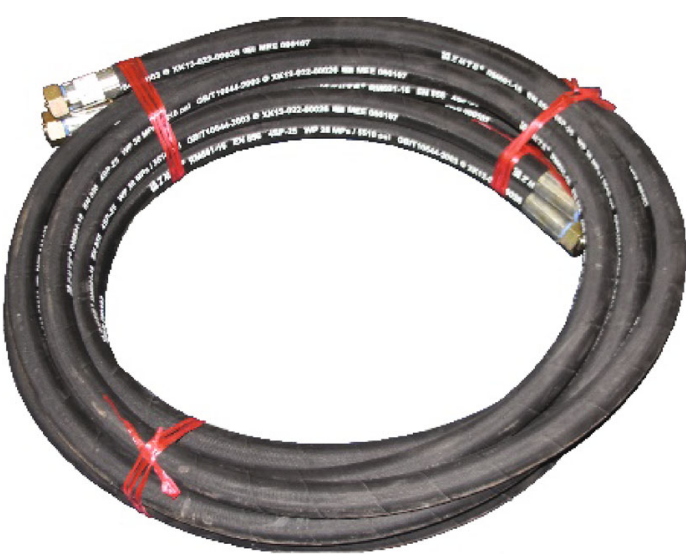

(d) High-pressure hose

FIGURE 6: Main components and physical drawing.

is orthogonal to the impact surface, the impact plane of the jet turns backward to the downstream and the turning degree changes with the shape of the rock mass into a depression, as shown in Figure 4.

\subsection{Overview of the High-Pressure Water Jet Reaming} Technology and the Complete Set of Equipment Developed. High-pressure water jet drilling and reaming are a kind of technology to improve the efficiency of gas drainage. The drilling rig is used to drive the high-pressure reaming drill pipe and reaming bit to rotate. The high-pressure water in the water storage tank strikes, cuts, or peels the coal wall of the borehole through the high-pressure hose, highpressure rotary tail, high-pressure reaming drill pipe, and reaming bit nozzle. Through the high-pressure reaming drill pipe moving along the axial direction of the drilling hole, the radial continuous reaming of the whole drilling hole is formed; so as to expand the diameter of the drilling hole, the exposed area of the coal seam and the radial pressure relief range of the drilling hole must be increased. And then, the coal seam permeability and gas drainage effect must be improved and the coal seam gas pressure must be further reduced. At the same time, after the coal seam is wetted, the elasticity of coal decreases and the initial velocity of coal pressure relief and gas emission decreases, which is also conducive to the prevention and control of coal and gas outburst. The main structure, main components, and field operation process of the device are shown in Figures 5, 6, and 7.

The integrated drilling and expanding device can adapt to different drilling inclination and coal seam characteristics for the hole expanding operation. In the process of highpressure reaming in the soft and low-permeability outburst coal seam, due to the large amount of slag in the borehole, the drilling rig is used to drive the drill pipe to rotate and increase the high-pressure water flow. The problem of difficult slag discharge in hole enlargement is solved. The diameter of the coal hole increases 3 9 times after hole enlargement.

3.3. The Field Test Plan. The integrated drilling and expanding device can realize the dual functions of drilling and high- 


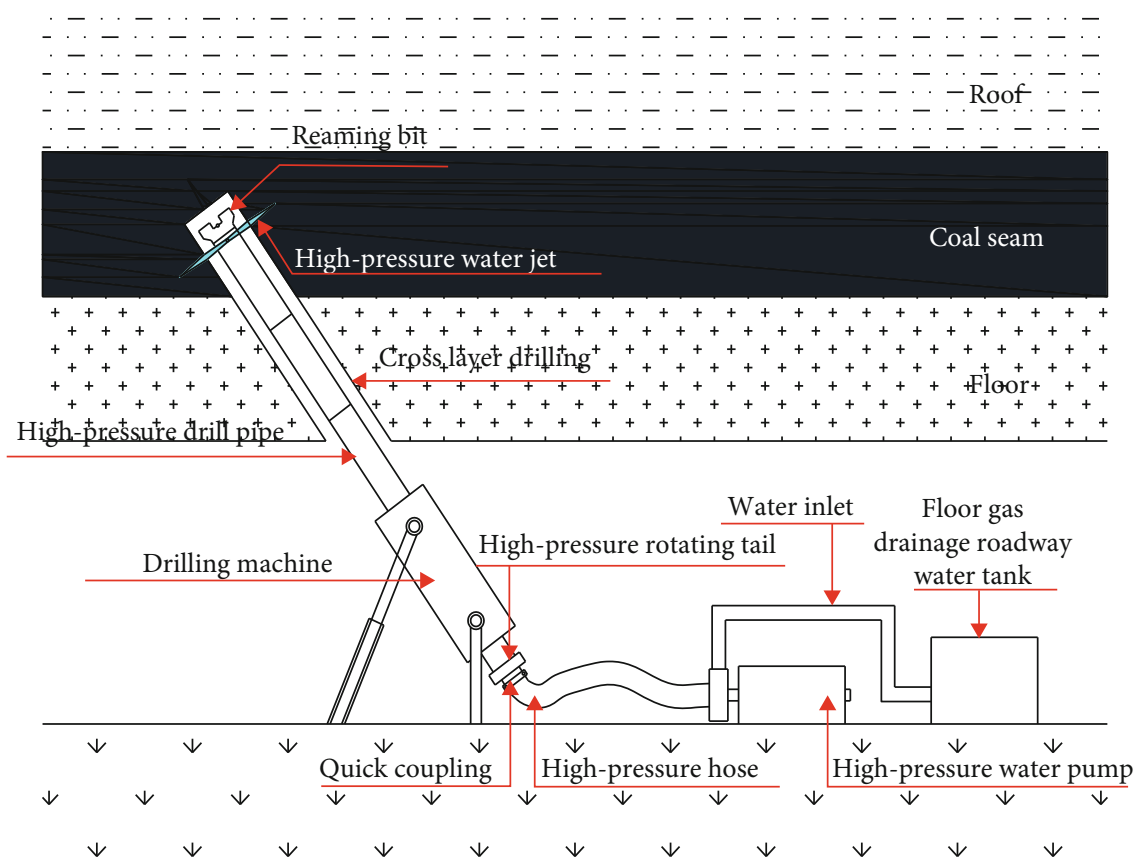

FIgUre 7: Diagram of the layout of the device on site.

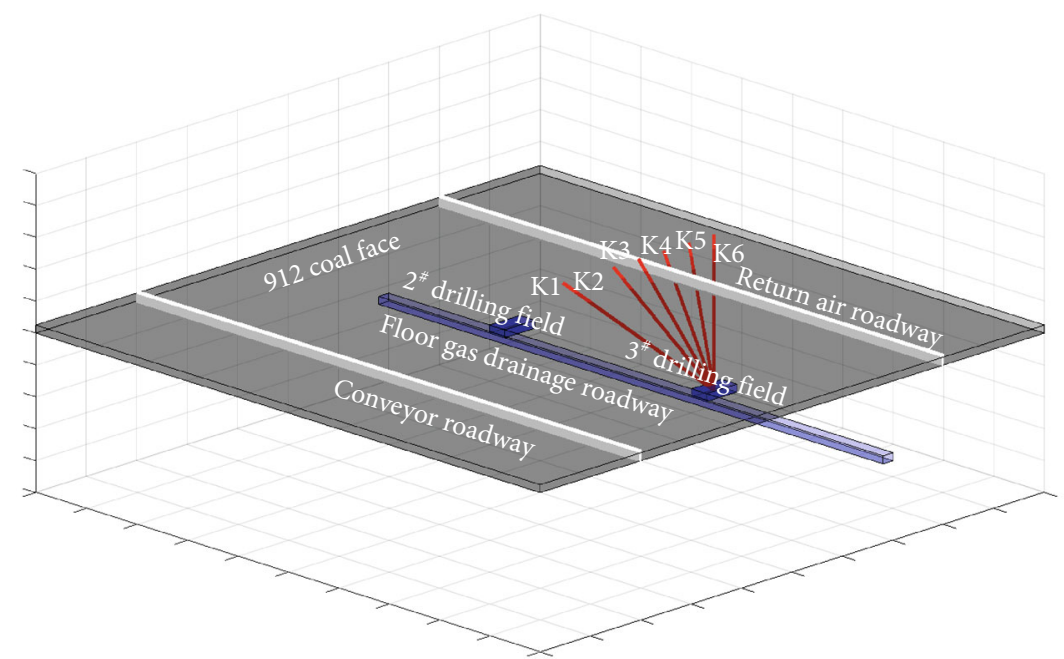

Figure 8: Diagram of the designed project.

TABLE 1: Verification of hole drilling parameters.

\begin{tabular}{lccccc}
\hline Borehole number & Opening position & Dip angle $\left(^{\circ}\right)$ & Azimuth $\left(^{\circ}\right)$ & Length $(\mathrm{m})$ & Remarks \\
\hline J1 & 86.3 & 233.5 & 34 & K1: $3.5 \mathrm{~m}$ \\
J2 & $0.5 \mathrm{~m}$ area of the K1 opening point & 75 & 217.5 & 35.2 & K1: $4 \mathrm{~m}$ \\
J3 & 78.9 & 183 & 35 & K1: $5 \mathrm{~m}$ \\
J4 & 71.3 & 176.4 & 37.5 & K4: $3.5 \mathrm{~m}$ \\
J5 & & 60.6 & 176.4 & 40.7 & K4: $4 \mathrm{~m}$ \\
J6 & & 65.3 & 189 & 39.1 & K4: $5 \mathrm{~m}$ \\
J7 & & 69.8 & 125.2 & 40.3 & K5: $5 \mathrm{~m}$ \\
J8 & $0.5 \mathrm{~m}$ area of the K4 opening point & 61.4 & 125.2 & 42.8 & K5: $5 \mathrm{~m}$ \\
\hline
\end{tabular}


TABLE 2: Investigation table of reaming borehole drainage data.

\begin{tabular}{|c|c|c|c|c|c|}
\hline Time (d) & Concentration (\%) & Negative pressure $(\mathrm{kPa})$ & Mixing amount $\left(\mathrm{m}^{3} / \mathrm{min}\right)$ & Flow $\left(\mathrm{m}^{3} / \mathrm{min}\right)$ & Daily discharge of single hole $\left(\mathrm{m}^{3} / \mathrm{d}\right)$ \\
\hline 1 & 65 & 14.0 & 1.34 & 0.87 & 178.74 \\
\hline 2 & 57 & 19.0 & 1.32 & 0.76 & 156.73 \\
\hline 3 & 54 & 19.9 & 1.30 & 0.71 & 146.98 \\
\hline 4 & 54 & 19.3 & 1.28 & 0.69 & 142.70 \\
\hline 5 & 55 & 18.4 & 1.23 & 0.67 & 137.12 \\
\hline 6 & 54 & 17.8 & 1.16 & 0.61 & 126.04 \\
\hline 7 & 53 & 17.3 & 1.07 & 0.56 & 115.58 \\
\hline 8 & 55 & 17.1 & 0.98 & 0.54 & 111.59 \\
\hline 9 & 58 & 16.9 & 0.88 & 0.53 & 108.45 \\
\hline 10 & 60 & 16.8 & 0.78 & 0.49 & 100.15 \\
\hline 11 & 63 & 16.7 & 0.69 & 0.44 & 90.72 \\
\hline 12 & 70 & 16.6 & 0.62 & 0.41 & 84.81 \\
\hline 13 & 75 & 16.7 & 0.56 & 0.39 & 79.70 \\
\hline 14 & 74 & 17.0 & 0.51 & 0.35 & 71.92 \\
\hline 15 & 68 & 17.4 & 0.48 & 0.31 & 62.46 \\
\hline 16 & 60 & 18.0 & 0.45 & 0.27 & 53.46 \\
\hline 17 & 53 & 18.5 & 0.43 & 0.23 & 47.03 \\
\hline 18 & 50 & 18.9 & 0.41 & 0.21 & 44.15 \\
\hline 19 & 53 & 18.9 & 0.38 & 0.20 & 42.03 \\
\hline 10 & 59 & 18.4 & 0.36 & 0.19 & 39.96 \\
\hline 21 & 66 & 17.5 & 0.33 & 0.18 & 38.01 \\
\hline 22 & 70 & 16.1 & 0.31 & 0.18 & 36.27 \\
\hline 23 & 70 & 14.7 & 0.28 & 0.17 & 34.81 \\
\hline 24 & 63 & 13.6 & 0.26 & 0.16 & 33.56 \\
\hline 25 & 56 & 13.3 & 0.24 & 0.15 & 31.80 \\
\hline 26 & 54 & 14.2 & 0.23 & 0.14 & 28.90 \\
\hline 27 & 56 & 16.2 & 0.23 & 0.12 & 25.33 \\
\hline 28 & 62 & 18.7 & 0.23 & 0.11 & 21.80 \\
\hline 29 & 71 & 19.3 & 0.20 & 0.09 & 19.03 \\
\hline 30 & 80 & 13.9 & 0.11 & 0.09 & 17.74 \\
\hline
\end{tabular}

pressure expanding at the same time (the diameter of the high-pressure reaming drill bit is $\Phi 108 \mathrm{~mm}$, and the radial nozzle diameter of the reamer bit is $\Phi 4.0 \mathrm{~mm}$ ). There is no need to replace the drilling tool repeatedly. Before the drilling hole is opened to the coal, the front end of the bit will water out to realize the normal drilling function of the low-pressure water $\mathrm{p}$. The reaming pressure of the high-pressure water pump is set when coal is seen in the drilling hole. Once the water pressure in front of the reaming nozzle exceeds $5 \mathrm{MPa}$, the reaming nozzle can be closed. During reaming operation, high-pressure water passes through the high-pressure hose and high-pressure reaming drill pipe to the integrated drilling and reaming bit. The reaming nozzle on the drill bit is driven by the highpressure drill pipe to cut the hole wall. At this time, the drilling machine can move the high-pressure drill pipe at an appropriate speed along the drilling axis to start the reaming operation. During reaming, the drilling speed of the drill pipe shall not be greater than $0.05 \mathrm{~m} / \mathrm{min}$. At the same time, it is necessary to strengthen the monitoring of gas emission within $20 \mathrm{~m}$ around the drilling rig to prevent gas overrun accidents during hole enlargement. When the hole has the threat of blowout, the drilling speed should be reduced to $0.02 \sim 0.03 \mathrm{~m} / \mathrm{min}$. When the drill pipe moves a certain length, the water supply can be suspended, one or more drill pipes can be added or removed, and the reaming can be continued until the length of the reaming section meets the design requirements.

Six boreholes K1 K6 were successively constructed in the no. 3 drilling field of the $2^{\#}$ floor drainage roadway as shown in Figure 8. After $\mathrm{K} 1, \mathrm{~K} 4$, and $\mathrm{K} 5$ are constructed to the coal seam, the original gas content is measured by pressure change air sampling. The pressure levels of the high-pressure water pump were $8,10,13,15$, and $17 \mathrm{MPa}$ during the reaming process. At the same time, the particle size of pulverized coal and the discharge of pulverized coal were observed. After the completion of each drilling construction, the $\Phi 50 \mathrm{~mm}$ gate valve shall be used to close and the gas gathering and water discharging device shall be installed together after the completion 


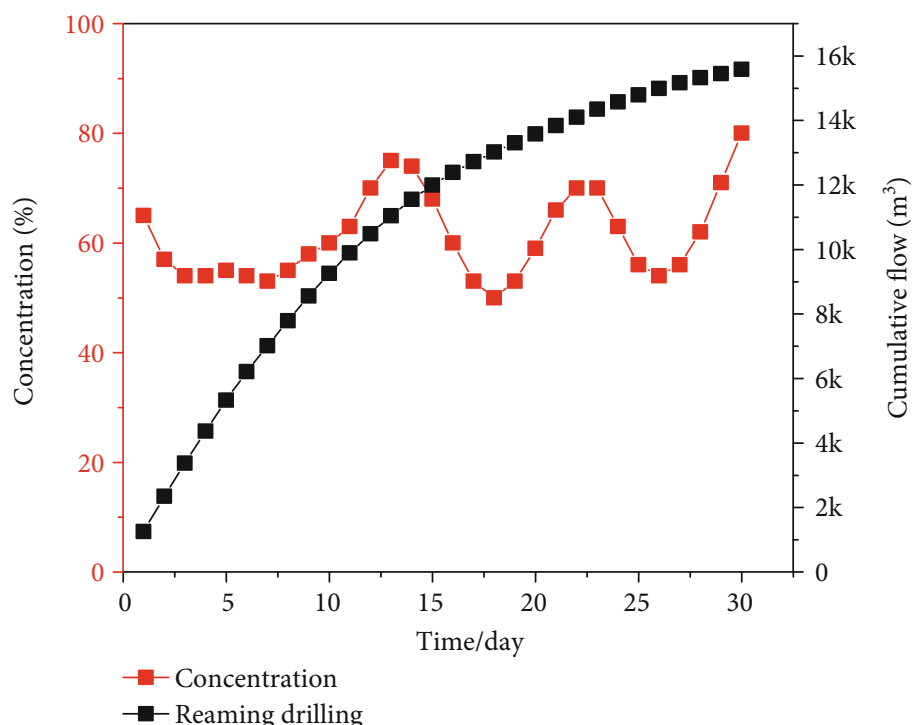

FiguRE 9: Change trend graph of gas drainage concentration and cumulative gas drainage scalar over time for the entire group of reaming holes $\mathrm{K} 1 \sim \mathrm{K} 6$ for 30 consecutive days.

TABLE 3: Investigation table of unreamed conventional borehole drainage data.

\begin{tabular}{|c|c|c|c|c|c|}
\hline Time (d) & Concentration (\%) & Negative pressure $(\mathrm{kPa})$ & Mixing amount $\left(\mathrm{m}^{3} / \mathrm{min}\right)$ & Flow $\left(\mathrm{m}^{3} / \mathrm{min}\right)$ & Daily discharge of single hole $\left(\mathrm{m}^{3} / \mathrm{d}\right)$ \\
\hline 1 & 62 & 15 & 0.34 & 0.21 & 50.74 \\
\hline 2 & 61 & 18 & 0.34 & 0.21 & 49.30 \\
\hline 3 & 60 & 18.8 & 0.34 & 0.20 & 48.69 \\
\hline 4 & 59 & 19.1 & 0.34 & 0.20 & 47.59 \\
\hline 5 & 55 & 19 & 0.35 & 0.19 & 45.94 \\
\hline 6 & 53 & 18 & 0.33 & 0.17 & 41.71 \\
\hline 7 & 51 & 17 & 0.31 & 0.16 & 38.51 \\
\hline 8 & 48 & 16.9 & 0.32 & 0.15 & 36.92 \\
\hline 9 & 46 & 16.8 & 0.33 & 0.15 & 36.55 \\
\hline 10 & 46 & 16.8 & 0.30 & 0.14 & 33.41 \\
\hline 11 & 44 & 16.9 & 0.28 & 0.12 & 29.92 \\
\hline 12 & 44 & 16.6 & 0.27 & 0.12 & 28.19 \\
\hline 13 & 42 & 17 & 0.27 & 0.11 & 27.53 \\
\hline 14 & 41 & 16.5 & 0.25 & 0.10 & 24.35 \\
\hline 15 & 39 & 16.6 & 0.23 & 0.09 & 21.26 \\
\hline 16 & 38 & 18 & 0.20 & 0.08 & 18.57 \\
\hline 17 & 36 & 18.2 & 0.19 & 0.07 & 16.73 \\
\hline 18 & 35 & 18.5 & 0.18 & 0.06 & 15.27 \\
\hline 19 & 33 & 18.8 & 0.18 & 0.06 & 14.12 \\
\hline 10 & 32 & 18.9 & 0.18 & 0.06 & 13.71 \\
\hline 21 & 31 & 17.5 & 0.17 & 0.05 & 12.99 \\
\hline 22 & 30 & 17.6 & 0.18 & 0.05 & 12.71 \\
\hline 23 & 29 & 17.7 & 0.17 & 0.05 & 11.72 \\
\hline 24 & 27 & 15 & 0.17 & 0.05 & 11.16 \\
\hline 25 & 26 & 14.8 & 0.16 & 0.04 & 10.29 \\
\hline 26 & 24 & 15.2 & 0.17 & 0.04 & 9.63 \\
\hline 27 & 22 & 14.6 & 0.16 & 0.03 & 8.32 \\
\hline 28 & 20 & 14.5 & 0.16 & 0.03 & 7.59 \\
\hline 29 & 19 & 14.4 & 0.14 & 0.03 & 6.35 \\
\hline 30 & 19 & 14.3 & 0.14 & 0.03 & 6.35 \\
\hline
\end{tabular}




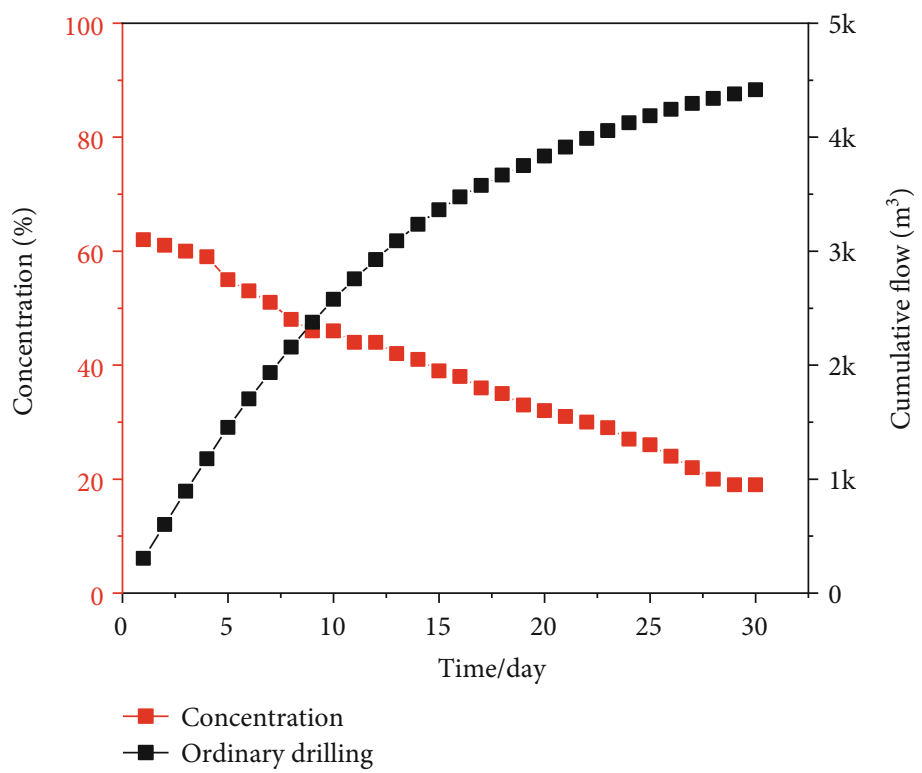

FIGURE 10: Change trend graph of gas drainage concentration and cumulative gas drainage scalar over time for six unreamed conventional boreholes for 30 consecutive days.

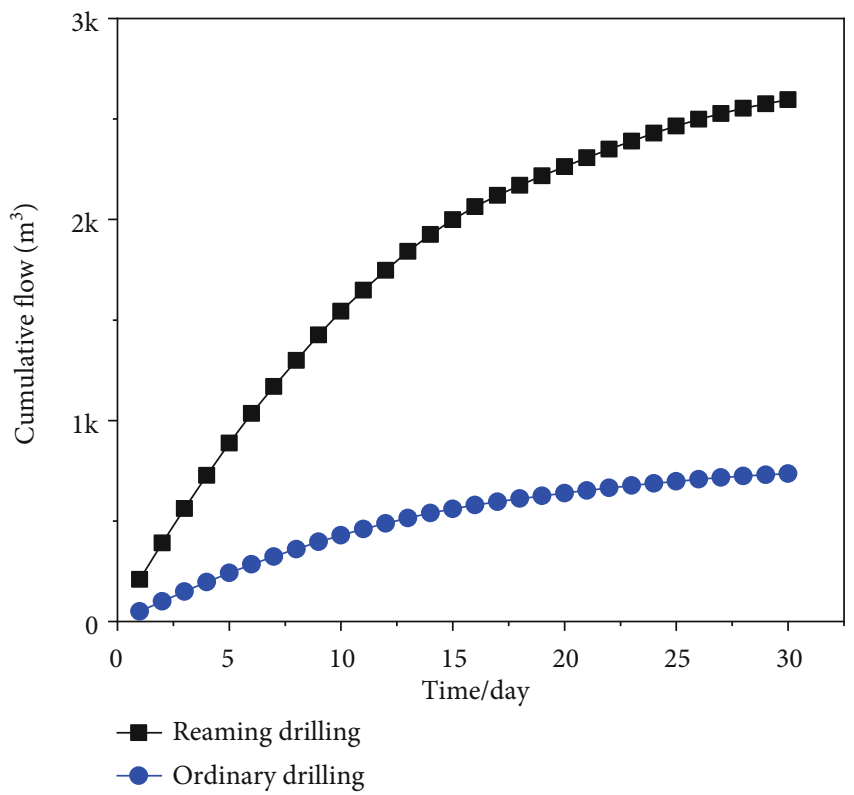

FIGURE 11: Contrast curve of the cumulative extraction scalar volume between a single-reamed borehole and a single-unreamed conventional borehole for 30 consecutive days.

of all drilling construction. Then, the $\Phi 200 \mathrm{~mm}$ orifice flowmeter shall be connected and it must be connected to the low pressure extraction pipeline for extraction. The concentration, negative pressure, differential pressure, and other parameters of the orifice plate were inspected once a day until the flow attenuation was stable. The construction of the $\mathrm{K} 1$ drill hole was started, and the cast iron gate valve was timely installed and closed one by one until the construction of the last drill hole K6 was completed. The gate valve of all the investigated boreholes must be opened and they must be connected to the drainage pipeline installed with the $\Phi 200 \mathrm{~mm}$ orifice flowmeter for drainage. At the same time, the gas flow of the boreholes must be monitored.

In order to investigate the effect of high-pressure water jet drilling and expansion integration on pressure relief and permeability enhancement of coal seam 9, eight verification holes were constructed in the no. 3 drilling field two months after the test. Three verification holes are designed, which are $3.5 \mathrm{~m}, 4 \mathrm{~m}$, and $5 \mathrm{~m}$ (horizontal distance) away from the coal point of $\mathrm{K} 1$ and $\mathrm{K} 4$. Two verification holes with the distance of $4 \mathrm{~m}$ and $5 \mathrm{~m}$ (horizontal distance) from the coal point of the $\mathrm{K} 5$ borehole are designed. The design parameters are shown in Table 1. 
TABLE 4: Statistical table of drilling construction and residual gas content.

\begin{tabular}{|c|c|c|c|c|c|}
\hline Borehole number & Dip angle $\left({ }^{\circ}\right)$ & Azimuth $\left({ }^{\circ}\right)$ & Design hole depth $(\mathrm{m})$ & Actual hole depth (m) & Residual gas content $\left(\mathrm{m}^{3} / \mathrm{t}\right)$ \\
\hline J1 & 86.3 & 233.5 & 34 & 35 & 7.89 \\
\hline $\mathrm{J} 2$ & 75 & 217.5 & 35.2 & 39 & 4.55 \\
\hline $\mathrm{J} 3$ & 78.9 & 183 & 35 & 36.5 & 1.63 \\
\hline J4 & 71.3 & 176.4 & 37.5 & 36 & 7.97 \\
\hline J5 & 60.6 & 176.4 & 40.7 & 40 & 11.01 \\
\hline J6 & 65.3 & 189 & 39.1 & 36 & 11.37 \\
\hline J7 & 69.8 & 125.2 & 40.3 & 35 & 9.35 \\
\hline J8 & 61.4 & 125.2 & 42.8 & 41 & 7.65 \\
\hline
\end{tabular}

\section{Analysis of Monitoring Results}

4.1. Analysis of Drainage Results. The daily gas flow, gas concentration, suction negative pressure of the entire group of reaming boreholes $\mathrm{K} 1 \sim \mathrm{K} 6$, and drainage scalar of a singlereaming borehole for 30 consecutive days are shown in Table 2. The change trend graph of gas drainage concentration and cumulative gas drainage scalar over time for the entire group of reaming holes $\mathrm{K} 1 \sim \mathrm{K} 6$ for 30 consecutive days are shown in Figure 9. It can be seen that the mixed drainage concentration of the 6 reaming boreholes for 30 consecutive days did not change much and they were all maintained at a high level and there was no significant decrease.

The daily gas flow, gas concentration, drainage negative pressure of the 6 unreamed conventional boreholes corresponding to the reamed boreholes, and drainage scalar of a single-unreamed conventional borehole for 30 consecutive days are shown in Table 3 . The change trend graph of gas drainage concentration and cumulative gas drainage scalar over time for six unreamed conventional boreholes for 30 consecutive days are shown in Figure 10. It can be seen that the mixed drainage concentration of the six conventional boreholes for 30 consecutive days has changed greatly. The initial drainage concentration is high, and then, it has been in a downward trend. After the 28th day, the concentration fell below 20\%. It should be noted that the drill bit diameter of the unreamed comparison drill holes are also $\Phi 108 \mathrm{~mm}$.

In Figures 9 and 10, it can be seen that both the reamed boreholes and the unreamed conventional boreholes have relatively large gas drainage scalar at the initial stage. Among them, a single-reamed borehole has an average daily gas drainage rate for 10 consecutive days at the initial stage, the average daily drainage volume reached more than $100 \mathrm{~m}^{3} / \mathrm{d}$, and the average daily drainage scalar volume of a single conventional borehole for the initial 6 consecutive days also reached more than $60 \mathrm{~m}^{3} / \mathrm{d}$. With the extension of the drainage time, the scalar drainage of the two types of boreholes gradually decreases. After 28 days of continuous drainage from the reaming borehole, the average daily drainage volume of a single borehole fell below $20 \mathrm{~m}^{3} / \mathrm{d}$; after 24 days of conventional drilling, the average daily drainage volume of a single borehole fell to $10 \mathrm{~m}^{3} / \mathrm{d}$. It can be seen that both types of borehole drainage scalar decay speeds are very fast. The reason is that in the early stage of drainage, the coal seam gas desorption rate is faster and the drilling integrity is better, so the drainage scalar of the two types of drilling is relatively large; as the drainage time increases, the coal seam gas desorption rate becomes slower and the drilling the holes are gradually blocked by pulverized coal, resulting in significantly lower extraction scalar for both types of boreholes. The drainage negative pressure of the two types of boreholes is between 14 and $19 \mathrm{kPa}$, but in order to achieve better drainage effect, relatively high drainage negative pressure should be used in the early stage of drainage and relatively low drainage pressure should be used in the later stage of drainage with negative pressure.

It can be seen in Figure 11 that the unreamed conventional borehole has a single-hole initial gas drainage rate of $50.74 \mathrm{~m}^{3} / \mathrm{d}$ and a single-hole cumulative gas drainage rate of $736.12 \mathrm{~m}^{3}$ within 30 days. The initial single-hole gas drainage volume of the reaming borehole is $178.74 \mathrm{~m}^{3} / \mathrm{d}$, and the cumulative single-hole gas drainage volume in 30 days is $2227.57 \mathrm{~m}^{3}$. After reaming, the initial gas drainage scalar of a single hole increased 3.52 times of the original unreamed conventional drilling and the average cumulative gas drainage scalar of a single hole reached 3.03 times of the original unreamed conventional drilling. A very good drainage effect has been achieved.

4.2. Verification of the Extraction Radius of Cross Layer Drilling. All the verified boreholes J1 J8 were constructed to the coal seam 9, and the coal samples were taken to test the residual gas content of the coal seam 9 by means of fixed-point sampling. The completion parameters of the boreholes and the measurement results of the residual gas content are shown in Table 4.

It can be seen in Table 4 that

(1) The residual gas contents at $2.3 \mathrm{~m}, 3.1 \mathrm{~m}$, and $4.9 \mathrm{~m}$ from the coal spot in borehole $\mathrm{K} 1$ are $1.63 \mathrm{~m}^{3} / \mathrm{t}$, $4.55 \mathrm{~m}^{3} / \mathrm{t}$, and $7.89 \mathrm{~m}^{3} / \mathrm{t}$, respectively, which are $6.85 \mathrm{~m}^{3} / \mathrm{t}, 3.93 \mathrm{~m}^{3} / \mathrm{t}$, and $0.59 \mathrm{~m}^{3} / \mathrm{t}$ lower, respectively, than the original gas content $8.48 \mathrm{~m}^{3} / \mathrm{t}$ in borehole $\mathrm{K} 1$. The residual gas content at $5.7 \mathrm{~m}$ from the coal spot in borehole K4 is $7.97 \mathrm{~m}^{3} / \mathrm{t}$, which is $2.49 \mathrm{~m}^{3} / \mathrm{t}$ lower than the original gas content of $10.46 \mathrm{~m}^{3} / \mathrm{t}$ in borehole K4. The residual gas content at $5.1 \mathrm{~m}$ from the coal spot in borehole $\mathrm{K} 5$ is $7.65 \mathrm{~m}^{3} / \mathrm{t}$, which is $1.43 \mathrm{~m}^{3} / \mathrm{t}$ lower than the original gas content of $9.08 \mathrm{~m}^{3} / \mathrm{t}$ in borehole $\mathrm{K} 5$. This shows that the gas content near the borehole is significantly reduced due to the continuous extraction of the reamed 
borehole and the closer it is to the borehole, the greater the decrease in gas content

(2) However, the measured gas contents at $6.2 \mathrm{~m}$ and $6.7 \mathrm{~m}$ from the coal spot in borehole $\mathrm{K} 4$ are $11.01 \mathrm{~m}^{3} / \mathrm{t}$ and $11.37 \mathrm{~m}^{3} / \mathrm{t}$, respectively, which are slightly larger than the original gas content in borehole K4, indicating that the two areas are not affected by K4 borehole drainage. Similarly, the measured gas content at $5.9 \mathrm{~m}$ from the coal spot of borehole $\mathrm{K} 5$ is $9.35 \mathrm{~m}^{3} / \mathrm{t}$, which is also greater than the original gas content of borehole $\mathrm{K} 5$, indicating that this location is not affected by the drainage of borehole $\mathrm{K} 5$

In summary, from the measurement results of the gas content in the verified borehole, the area $5.9 \mathrm{~m}$ away from the reaming borehole and beyond is basically not affected by drainage. Therefore, the drainage radius of the reaming borehole for two months is between $5.7 \mathrm{~m}$ and $5.9 \mathrm{~m}$, the residual gas content in this range can generally be reduced to less than $8 \mathrm{~m}^{3} / \mathrm{t}$, and the closer it is to the drainage borehole, the greater the reduction of the gas content.

Comparing the extraction radius of $2.6 \mathrm{~m}$ in the unreamed conventional floor through-bed drainage borehole in the test area coal seam 9 during the two months of extraction, it is concluded that the high-pressure water jet drilling and expansion integrated technology makes the coal seam 9 extraction radius comparably increased to 2.19 2.27 times of the original one, greatly reducing the amount of drilling engineering and drastically shortening the extraction time. Even considering that the amount of slag discharged during the reaming drilling construction is relatively large and it takes a certain amount of time to clean up, the construction time of each reaming drilling remains basically the same as that of conventional drilling. Most importantly, the drainage radius of the reaming hole has been increased to 2.19 2.27 times more than that of the original conventional drilling. Therefore, if the requirements of the drainage standards are the same and the drainage time is the same, the drilling volume can be greatly saved and the drilling volume can be saved by more than two-thirds in the test area alone. Similarly, if the requirements for the drainage standards are the same and the drilling engineering volume is the same, the time for drilling drainage to meet the standards can be greatly shortened, and theoretically, the drainage time can be shortened by more than one time.

\section{Conclusions}

This study has developed a new type of high-pressure water jet drilling and expansion integrated equipment and formed a mature process technology system. Field application shows that the equipment is easy to install and operate and is safe and reliable as a whole. It can better solve the gas control problem of soft and low-permeability coal seams under complex geological conditions.

Application of high-pressure water jet drilling and expansion-integrated antireflection measures can effectively improve the permeability of the coal seam and increase the gas drainage volume in the soft and low-permeability coal seam. After reaming, the initial gas drainage scalar of a single hole increased to 3.52 times of the original unreamed conventional drilling and the average cumulative gas drainage scalar of a single hole reached 3.03 times of the original unreamed conventional drilling. A very good drainage effect of drilling has been achieved.

After adopting high-pressure water jet drilling and expansion-integrated antireflection measures, most importantly, the drainage radius of the reaming hole has been increased to 2.19 2.27 times more than that of the original conventional drilling. It can greatly save the amount of drilling engineering and shorten the drainage standard time. Economy and time benefits are very significant.

\section{Data Availability}

The data used to support the findings of this study are available from the corresponding author upon request.

\section{Conflicts of Interest}

The authors declare no conflicts of interest.

\section{Acknowledgments}

This work was financially supported by the National Key Research and Development Program of China (2017YFC0804206 and 2017YFC0804209) and the Anhui Provincial Natural Science Foundation (2008085ME147).

\section{References}

[1] F. Q. Ren, C. Zhu, and M. C. He, "Moment tensor analysis of acoustic emissions for cracking mechanisms during schist strain burst," Rock Mechanics and Rock Engineering, vol. 53, no. 1, article 1897, pp. 153-170, 2020.

[2] C. Zhu, M. C. He, M. Karakus, X. B. Cui, and Z. G. Tao, "Investigating toppling failure mechanism of anti-dip layered slope due to excavation by physical modelling," Rock Mechanics and Rock Engineering, vol. 53, no. 11, pp. 5029-5050, 2020.

[3] L. Wang, Z. Lu, D. P. Chen et al., "Safe strategy for coal and gas outburst prevention in deep-and-thick coal seams using a soft rock protective layer mining," Safety Science, vol. 129, article 104800, 2020.

[4] A. P. He, H. Fu, B. J. Huo, and C. J. Fan, "Permeability enhancement of coal seam by lower protective layer mining for gas outburst prevention," Shock and Vibration, vol. 2020, Article ID 8878873, 12 pages, 2020.

[5] H. Li, J. K. Ma, Z. Q. Wang, W. Wang, and Y. W. Liu, "A gas outburst prevention and control strategy for single thick coal seams with high outburst risk: a case study of Hudi Coal Mine in Qinshui Basin," Energy Science and Engineering, vol. 8, no. 7, pp. 2471-2491, 2020.

[6] G. Fu, X. C. Xie, Q. S. Jia, W. Q. Tong, and Y. Ge, "Accidents analysis and prevention of coal and gas outburst: Understanding human errors in accidents," Process Safety and Environmental Protection, vol. 134, pp. 1-23, 2020.

[7] D. D. Chen, W. R. He, S. R. Xie, F. L. He, Q. Zhang, and B. B. Qin, "Increased permeability and coal and gas outburst prevention using hydraulic flushing technology with cross-seam 
borehole," Journal of Natural Gas Science and Engineering, vol. 73, article 103067, 2020.

[8] L. Cheng, Z. L. Ge, J. F. Chen, L. S. Zou, Y. G. Cheng, and S. Q. Xiao, "Hydraulic fracturing and its effect on gas extraction and coal and gas outburst prevention in a protective layer: a case study in China," International Journal of Oil Gas and Coal Technology, vol. 23, no. 4, pp. 427-449, 2020.

[9] P. L. Zhou, Y. H. Zhang, Z. A. Huang, Y. K. Gao, H. Wang, and Q. Luo, "Coal and gas outburst prevention using new high water content cement slurry for injection into the coal seam," International Journal of Mining Science and Technology, vol. 27, no. 4, pp. 669-673, 2017.

[10] V. Hudecek, P. Zapletal, M. Stonis, and R. Sojka, "Results from dealing with rock and gas outburst prevention in the Czech Republic / Efekty Działań Mających Na Celu Zapobieganie Wybuchom Skał I Gazu, Podejmowanych W Republice Czeskiej," Archives of Mining Sciences, vol. 58, no. 3, pp. 779-787, 2013.

[11] Y. Cheng, Y. L. Ma, and Y. L. Zhang, "Prevention and cure mechanism of coal and gas outburst by injecting heat into coal seam," Disaster Advances, vol. 5, no. 4, pp. 1243-1246, 2012.

[12] V. Hudecek and M. Stonis, "Forecast and prevention of coal and gas outbursts in the case of application of a new mining method-drilling of a coal pillar," Acta Montanistica Slovaca, vol. 15, no. 2, pp. 102-108, 2010.

[13] M. B. Díaz Aguado and C. González Nicieza, "Control and prevention of gas outbursts in coal mines, Riosa-Olloniego coalfield, Spain," International Journal of Coal Geology, vol. 69, no. 4, pp. 253-266, 2007.

[14] F. Yang, Z. L. Ge, J. F. Chen, L. Cheng, H. B. Lei, and L. S. Zou, "A comprehensive gas extraction system coupling high-level suction roadway and boreholes for gas disaster prevention in closely-spaced multiple coal seams," Energy Sources Part ARecovery Utilization and Environmental Effects, Article ID 1841853, 2020.

[15] C. L. Zhang, E. Y. Wang, J. Xu, and S. J. Peng, "A new method for coal and gas outburst prediction and prevention based on the fragmentation of ejected coalFuel," 2020.

[16] B. Wang, "Comprehensive prevention and control of coal and gas outburst in south second well of Liziya coal mine," in IOP Conference Series: Earth and Environmental Science, vol. 558, article 022020, IOP Institute of Physics, 2020.

[17] V. Tarasov and A. Fomin, "Coal and gas outburst prevention in longwalls by means of powered support unit of new type," E3S Web of Conferences, vol. 105, article 01030, 2019.

[18] J. F. Zhang, R. Y. Wang, F. F. Yang et al., "Discussion on the mechanism of coal and gas outburst prevention and control by the coal seam water injection," in IOP Conference Series: Earth and Environmental Science, vol. 252, article 052090, IOP Institute of Physics, 2019.

[19] C. Zhu, X. D. Xu, X. T. Wang et al., "Experimental investigation on nonlinear flow anisotropy behavior in fracture media," Geofluids, vol. 2019, no. 9, pp. 1-9, 2019.

[20] Z. Li, H. Liu, Z. Dun, L. Ren, and J. Fang, "Grouting effect on rock fracture using shear and seepage assessment," Construction and Building Materials, vol. 242, article 118131, 2020.

[21] Z. Li, S. Liu, W. Ren, J. Fang, Q. Zhu, and Z. Dun, "Multiscale laboratory study and numerical analysis of water-weakening effect on shale," Advances in Materials Science and Engineering, vol. 2020, Article ID 5263431, 14 pages, 2020.
[22] H. Gu, M. Tao, X. Li, W. Cao, and Q. Li, "Dynamic tests and mechanical model for water-saturated soft coal with various particle gradations," International Journal of Rock Mechanics and Mining Sciences, vol. 132, article 104386, 2020.

[23] H. Gu, M. Tao, W. Cao, J. Zhou, and X. Li, "Dynamic fracture behaviour and evolution mechanism of soft coal with different porosities and water contents," Theoretical and Applied Fracture Mechanics, vol. 103, article 102265, 2019.

[24] H. Ke, X. Binwei, L. Chengwei, and L. Yiyu, "Effective methane extraction radius after high-pressure water jet slotting," Geofluids, vol. 2020, Article ID 8820540, 12 pages, 2020.

[25] J. G. Zhang, Y. W. Wang, Z. L. Ge, S. Q. Xiao, H. Y. Zhao, and $X$. B. Huang, "Calculation model of high-pressure water jet slotting depth for coalbed methane development in underground coal mine," Applied Sciences-Basel, vol. 9, no. 23, article 5250, 2019.

[26] X. Jun, L. Yunpei, Z. Quanle, L. Lei, and L. Xuelong, "Elimination of coal and gas outburst risk of low-permeability coal seam using high-pressure water jet slotting technology: a case study in Shihuatian Coal Mine in Guizhou Province, China," Energy Science and Engineering, vol. 7, no. 4, pp. 1394-1404, 2019.

[27] Y. J. Zhang and Q. L. Zou, “A prediction model for the slot depth of high pressure water jet," Results in Physics, vol. 11, pp. 1105-1109, 2018.

[28] J. C. Zhao and D. Y. Guo, "Cracking mechanism of coal under high-pressure water jet and its applications for enhanced coalbed methane drainage," Arabian Journal of Geosciences, vol. 11, no. 15, article 3783, 2018.

[29] Z. L. Fang, Y. Kang, B. Yuan, X. F. Yang, and X. C. Wang, "Slotting radius prediction model of soft coal seams with high-pressure pulse water jet," Disaster Advances, vol. 6, Supplement 1, pp. 431-437, 2013.

[30] J. L. Liu and H. Si, "Gas disaster controlling based on high pressure water jet," Disaster Advances, vol. 5, no. 4, pp. 1663-1668, 2012.

[31] P. Borkowski, J. Borkowski, and M. Bielecki, "Coal disintegration using high pressure water jet," Tehnicki Vjesnik-Technical Gazette, vol. 19, no. 2, pp. 367-372, 2012.

[32] L. L. Cui, L. Q. An, W. L. Gong, and H. J. Jiang, "A novel process for preparation of ultra-clean micronized coal by high pressure water jet comminution technique," Fuel, vol. 86, no. 5-6, pp. 750-757, 2007.

[33] J. Zhao, G. C. Zhang, Y. J. Xu, A. G. Lin, J. Y. Zhao, and D. Y. Yang, "Enhancing rate of penetration in a tight formation with high-pressure water jet (HPWJ) via a downhole pressurized drilling tool," Journal of Petroleum Science and Engineering, vol. 174, pp. 1194-1207, 2019.

[34] H. H. Shi, G. S. Li, Z. W. Huang, J. B. Li, and Y. Zhang, "Study and application of a high-pressure water jet multi-functional flow test system," Review of Scientific Instruments, vol. 86, no. 12, article 125111, 2015.

[35] H. P. Chi, G. S. Li, Z. W. Huang, S. C. Tian, and X. Z. Song, "Maximum drillable length of the radial horizontal microhole drilled with multiple high-pressure water jets," Journal of Natural Gas Science and Engineering, vol. 26, pp. 1042 1049, 2015.

[36] J. L. Liu, J. P. Gao, M. Jianping, J. Wang, and D. Z. Sun, "Damage prediction model of high pressure water jet impinging coal rock based on PSO-BPNN," Proceedings of Science, vol. 299, pp. 1-6, 2017. 
[37] Y. J. Zhang and S. S. Guo, "Theoretical model of annular slotting depth for high pressure water jet and its application," Journal of the China Coal Society, vol. 44, pp. 126-132, 2019.

[38] Q. Meng, H. Wang, M. Cai, W. Xu, X. Zhuang, and T. Rabczuk, "Three-dimensional mesoscale computational modeling of soil-rock mixtures with concave particles," Engineering Geology, vol. 277, article 105802, 2020.

[39] Z. G. Tao, C. Zhu, M. C. He, and M. Karakus, “A physical modeling-based study on the control mechanisms of negative Poisson's ratio anchor cable on the stratified toppling deformation of anti- inclined slopes," International Journal of Rock Mechanics and Mining Sciences, vol. 138, p. 104632, 2021.

[40] Y. Wang, B. Zhang, S. H. Gao, and C. H. Li, "Investigation on the effect of freeze-thaw on fracture mode classification in marble subjected to multi-level cyclic loads," Theoretical and Applied Fracture Mechanics, vol. 111, p. 102847, 2021. 